\title{
Association between Objectively Measured Neighbourhood Built Environment and Walkability
}

\author{
Sabeen Qureshi ${ }^{1 a}$, Irfan Ahmed Memon ${ }^{2 a}$, Mir Aftab Hussain Talpur ${ }^{2 b}$
}

RECEIVED ON 02.05.2020, ACCEPTED ON 16.12.2020

\begin{abstract}
Some previous studies show that the majority of the urban planners and urban designers uses subjective measures to assess built environment attributes and neighbourhood walkability in Malaysia. However, those were using objective measures just evaluating one or two attributes of the built environment. Hence this paper focuses on objective measures of several built environment attributes that influence walkability. The paper links various objective measures of attributes of the built environment that influence walkability with objectively measured walkability. For this study data was obtained from Putrajaya review of the master plan and geographical information system data and walking distance obtained from the pedometer. The pedometers were deployed for 7-days period to capture an objective level of walkability. To achieve this study objective, a case study was conducted on three different residential precincts of Putrajaya, Malaysia and a randomly selected sample of 134 respondents from each of these three precincts was collected. To measure built environment attributes objectively, indices were used for quantifying compactness, diversity, accessibility and connectivity. The results indicate that overall indices values of Precinct 18 are high compared to precinct 9 and 8. The daily distance measured by pedometer is also high for Precinct 18. Findings of this study recommend that it is practicable for the urban designers and urban planners to employ these two objective methods. As in this study built environment index results correspond with pedometer recorded distance hence it is concluded that GIS data also has the potential to be used to construct measures of built environment attributes and to develop indices of walkability on neighbourhood scale both in Malaysia as well as in Pakistan.
\end{abstract}

Keywords: Built Environment, Geographical Information System (GIS), Walkability, Urban Design, Urban Planning, Putrajaya, Malaysia.

\section{INTRODUCTION}

$\mathrm{W}$ alking related studies in the past define walkability as, "the extent to which the built environment attracts the people by showing the friendliness to shopping, visiting a different destination, and enjoying or spending quality time in an area". The attributes of the built environment which have a positive influence on walking are commonly characterized by higher compactness, diverse mix land uses, high connectedness of street and a high value of the area used for retails i.e. the Floor Area Ratio (FAR). The direct measures of the associations between the attributes of built environment and walkability are still very rarely addressed in urban planning and urban design. The cooperation between urban planning specialists and built environment specialists for study of the walkability as an important element has become significant $[1,2]$.

Researchers have identified higher residential density, the degree of mixed land use, proximity to different destinations of interest, and street network connectivity as key factors to measure walkability in a built environment [3, 4]. During the past 60 years, research has proved that transport and land use are intricately linked. It was first originated in the

\footnotetext{
${ }^{1}$ Department of Architecture, Mehran University of Engineering and Technology, Jamshoro, Pakistan. Email: sabeen.qureshi@ faculty.muet.edu.pk (Corresponding Author)

${ }^{2}$ Department of City and Regional Planning, Mehran University of Engineering and Technology, Jamshoro, Sindh, Pakistan. Email: a aftab.talpur@ faculty.muet.edu.pk, birfan.ahmed@ faculty.muet.edu.pk

This is an open access article published by Mehran University of Engineering and Technology, Jamshoro under CC BY 4.0 International License.
} 
walking-scale neighbourhoods comprised of high residential density, mixed land uses and giving residents adequate transport mode choices. It also assures that urban form remains closely knit and therefore allows residents to drive less. Residents may take a shorter duration trip and therefore, will not start up their cars [5]. The neighbourhood form comprises of gross residential densities, diverse use of land, accessibility and connected street network. All of these characteristics are attributes of the built environment that defines neighbourhood form influence on non-motorized choice for travel. Compact land use patterns that are pedestrian-friendly designs comprise of higher gross densities of residence. The higher degree of diverse land use results in the reduction of overall travel by car for every single house hold as daily Vehicle Miles Travelled (VMT). The terms compactness and density are used interchangeably in the urban planning literature. Compactness is essential in comparison to conventional sprawl development in the suburbs in order to attain a potential advantage of sustainable urbanism for neighbourhoods $[6,7]$.

\section{METHODOLOGY}

\subsection{Objective measures of walkability using a pedometer and the neighbourhood's built environment attributes}

This paper explores objective measures of attributes of the built environment influencing walkability in three neighbourhoods of Putrajaya. Objective evaluation of a number of attributes of the built environment influencing walkability has been carried out using criteria of neighbourhood walkability defined in the model Neighbourhood Environment Walkability
Scale (NEWS). The attributes discussed in this model comprise of gross residential densities, diverse land uses, accessibility and connectedness of streets. With the help of different indexes, these attributes can be evaluated objectively. Also some features are measured using the GIS databases. All the information on land use characteristics and data was acquired from the Putrajaya master plan along with an ArcGIS shape files feature attributes and spatial information in ArcGIS version 10.2. This study explores association between built environment attributes' measures and total volume of walking in the Putrajaya Precincts 8, 9 and $18[8,9]$. Fig. 1 shows the conceptual framework for this study.

\subsection{Direct Observation Measures by Pedometer Digi-walker SW- 200}

The smart-phone pedometer applications and where the smart phones were not available among the children age 7-12 pedometer Digi-walker SW-200 were used for Direct observational measures (Objective) to get the total volume of walking steps [10]. These observations were carried out to ensure that there is a relationship between built environment attribute indexes influencing walking and actual pedometer measured walking distance recorded. For this study participants wore a Digi-Walker for 7 days meaning a whole one week. Also they were instructed to write down the number of steps and total distance covered by them each day, so that later they can calculate mean distance per day covered by them. There were 402 total number of participants and 134 participants from each precinct. The results are given in Table 1.

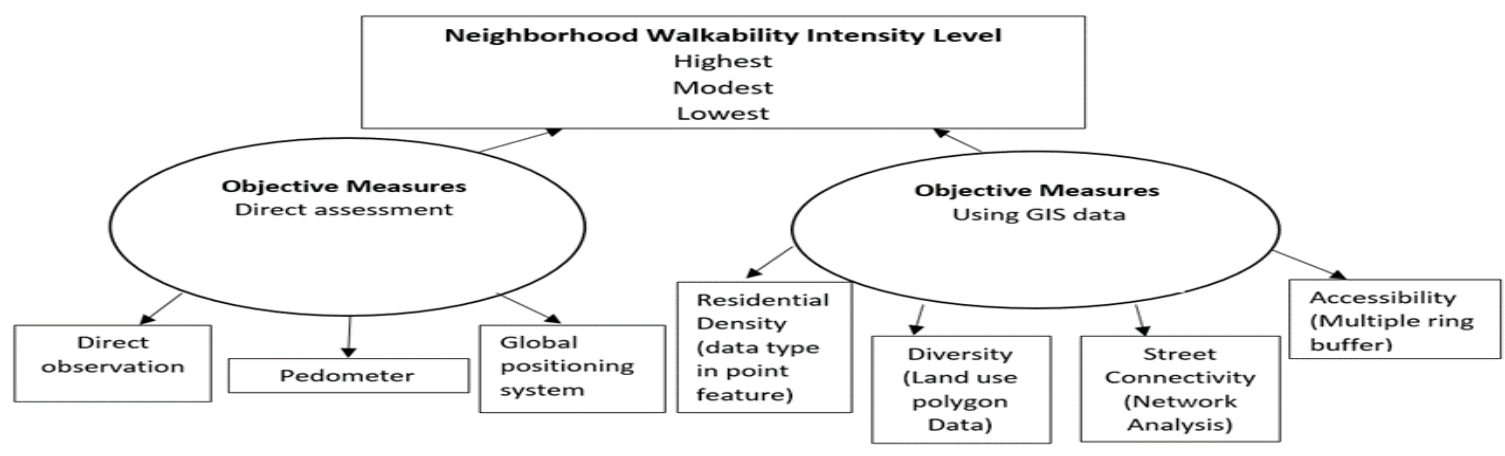

Fig. 1: Conceptual Framework of Research 
From the Precinct 18, respondent weekly walking log sheet recorded pedometer distance indicates that the highest walkability precinct is Precinct 18 in comparison to Precinct 8 and Precinct 9. Weekly walking $\log$ sheet obtained from Precinct 9 respondent indicates that compared to the other two precincts walkability in Precinct 9 is the modest. Weekly walking $\log$ sheet obtained from Precinct 8 respondents shows the lowest distances recorded in Precinct 8 therefore, least walkability in this precinct in comparison with Precinct 9 and Precinct 18.

\begin{tabular}{|c|c|c|c|}
\hline \multicolumn{4}{|c|}{ Table 1: Recorded Pedometer Walking Distance in } \\
each Precinct
\end{tabular}

\subsection{Objective Measures by the GIS data and built environment attributes Indices influencing walkability.}

For measuring the attributes of the built environment objectively in three different precincts of Putrajaya, the GIS data has been used as the research conducted on a walkability at the neighbourhood scale, primarily uses the GIS tool for objective measures, as the software manages databases comprising attributes along with a spatial reference. Data is obtained from the structure plan department of the Putrajaya Corporation and the GIS Department. The Putrajaya Corporation has collected information of each precinct on a numerous built environment's attributes. Social scientists in the field of urban design as well as urban planning have recognized housing, diverse land uses, accessibility and connectivity of streets as the significant attributes of a built environment that conceptualize the walkability indicators. In the previous studies they have been associated continuously with walkability [11].

\subsubsection{Compactness}

The planning of Putrajaya was inspired by Clarence Perry Walkability Neighbourhood concept [12, 13]. Therefore, the Precinct 18 having high walkability and Precinct 9 having moderate walkability both of them having gross residential densities higher than 10 dwelling units per acre as several studies found out that the neighbourhoods need more than 10 dwelling units/acre density to help create walkability neighbourhood. In Putrajaya Precinct 8 is the only precinct having a low gross density of 7.54 acres. For this study, there are numerous other indicators measured too for the assessment of neighbourhood compactness, as shown in Table 2.

\begin{tabular}{|c|c|c|c|}
\hline \multicolumn{4}{|c|}{$\begin{array}{c}\text { Table 2: Indicators Measured for the Assessment } \\
\text { of Compactness of each Precinct of Putrajaya }\end{array}$} \\
\hline $\begin{array}{c}\text { Compactness } \\
\text { determinants }\end{array}$ & $\begin{array}{c}\text { Highest } \\
\text { Walkability } \\
\text { (Precinct 8) }\end{array}$ & $\begin{array}{c}\text { Modest } \\
\text { Walkability } \\
\text { (Precinct 9) }\end{array}$ & $\begin{array}{c}\text { Lower } \\
\text { Walkability } \\
\text { (Precinct 8) }\end{array}$ \\
\hline $\begin{array}{c}\text { Gross } \\
\text { Densities }\end{array}$ & $\begin{array}{c}24.8 \\
\text { Housing } \\
\text { units/Acre }\end{array}$ & $\begin{array}{c}20.5 \\
\text { Housing } \\
\text { units/Acre }\end{array}$ & $\begin{array}{c}8.33 \\
\text { Housing } \\
\text { units/Acre }\end{array}$ \\
\hline $\begin{array}{c}\text { Single- } \\
\text { detached } \\
\text { Dwelling } \\
\text { Units }\end{array}$ & $\begin{array}{c}\text { No single } \\
\text { detached } \\
\text { dwellings } \\
\text { units }\end{array}$ & $\begin{array}{c}\text { No single } \\
\text { detached } \\
\text { dwellings } \\
\text { units }\end{array}$ & 1.8 \\
\hline $\begin{array}{c}\text { Detached } \\
\text { Plots per } \\
\text { hectare }\end{array}$ & $\begin{array}{c}\text { No single } \\
\text { detached } \\
\text { Residential } \\
\text { dwellings } \\
\text { units }\end{array}$ & $\begin{array}{c}\text { No single } \\
\text { detached } \\
\text { Residential } \\
\text { dwellings } \\
\text { units }\end{array}$ & $0.93 /$ Hectare \\
\hline $\begin{array}{c}\text { Gross Plot } \\
\text { Ratio }\end{array}$ & Up to 2.1 & Up to 1.6 & Up to 1.4 \\
\hline $\begin{array}{c}\text { Total } \\
\text { residential } \\
\text { units }\end{array}$ & 4984 & 4043 & 3556 \\
\hline
\end{tabular}

Table 2 shows that both the highest and modest walkability precinct have no single detached bungalow type houses; therefore, for single-detached plots or residential dwelling units density is not assessed. The main feature of high walkability Precinct 18 is a highly dense residential apartment building composed of 15 storeys whereas, moderate walkability Precinct 9 has high-density residential apartments building composed of 12 storeys. On the other hand, precinct 8 , which is low walkability, has 0.84 detached plots/single-family units per hectare. The prominent feature of precinct 8, which is low walkability is medium density residential development comprised of a walk up apartment composed of 6 storeys. Gross plot ratio is also highest in precinct 18 showing highest compactness and modest in precinct 
9 whereas low in precinct 8 .

\subsubsection{Diversity measures by Simpson Index}

Diversity is here related to the diverse land uses [14]. In Putrajaya, land uses have been classified into six different types of Housing: commercial, public, semipublic, recreational, services and infrastructure.

The Diversity " $\mathrm{D}$ " is calculated by using the following equation:

$\mathrm{D}=1-\left(\frac{\sum n^{\prime \prime}\left(n^{\prime \prime}-1\right)}{N^{\prime \prime}\left(N^{\prime \prime}-1\right)}\right)$

In this equation, $\mathrm{n}$ " denotes to the area of a particular category of uses for land (Housing, business, amenities for the public, recreational, infrastructure and services) in hectares. $\mathrm{N}$ " denotes to the entire area of the neighbourhood. The diversity " $\mathrm{D}$ " is expressed as a number extending from 0 to 1 . If the value of $D$ comes out closer to 0 that means there is no diversity whereas if the value comes near to 1 means, diversity is infinite.

\begin{tabular}{|c|c|c|c|}
\hline \multicolumn{3}{|c|}{ Table 3: Diversity Index Measures Values and } \\
Recorded Pedometer Distances \\
\hline Indicator & $\begin{array}{c}\text { Highest } \\
\text { walkability } \\
\text { (Precinct 18) }\end{array}$ & $\begin{array}{c}\text { Modest } \\
\text { walkability } \\
\text { (Precinct 9) }\end{array}$ & $\begin{array}{c}\text { Lower } \\
\text { walkability } \\
\text { (Precinct 8) }\end{array}$ \\
\hline $\begin{array}{c}\text { Diversity } \\
\text { measured by } \\
\text { Simpson } \\
\text { index }\end{array}$ & 0.941 & 0.632 & 0.309 \\
\hline $\begin{array}{c}\text { Mean walking } \\
\text { distance } \\
\text { (km/day) } \\
\text { (mean) } \\
(\mathrm{n}=402) \text { Km }\end{array}$ & 2.6 & 1.8 & 0.82 \\
\hline
\end{tabular}

Source: Putrajaya Review Master Plan, 1997 [16]

The Simpson diversity index values and Pedometer distance readings for each precinct are mentioned in Table 3 above. The value of the diversity is high (0.94) for Precinct 18 and therefore, associated with higher walked per person mean distance of $2.6 \mathrm{~km} / \mathrm{day}$. The second highest value of the Simpson diversity index was found to be 0.632 in Precinct 9 that is associated with modest walked per person mean distance of 1.8 . The value of diversity index is 0.309 for precinct 8 which is the lowest value and therefore associated with lowest walked per person mean distance of 0.82 . For both Precinct 18 and values for Precinct 9 are ranging from 0.6 to 0.9 that are good indicators of diversity suggesting that there are mix land uses. While Precinct 8 , exhibits low diversity, close to zero value. The pedometer readings are also found low in this precinct compared to Precinct 18 and Precinct 9.

\subsubsection{Accessibility Analysis}

The proposed distance in local plans of Putrajaya includes access to all amenities within the distance of $400 \mathrm{~m}$ to $1600 \mathrm{~m}$ from the school complex's center to precinct boundary. Clarence Perry initially developed this concept of walking catchments ranging from 400 $\mathrm{m}$ to $1600 \mathrm{~m}$ from his model neighbourhood unit that was comprised of an earlier illustrative planning model for neighbourhood development specifically for the urban areas [15].

For the urban planner, this model is intended to act as a framework towards an attempt to a proposed neighbourhood that is self-contained, functional and lively. According to the Putrajaya Review of Master Plan in every neighbourhood center, there would be a school complex comprising of elementary school, middle school, high school and a kindergarten within walking distance of the homes so the neighbourhood parks and open spaces must be placed within the walking catchment of 400 to 800 meter. In contrast, kindergarten preferably is within the walking catchment of $400 \mathrm{~m}$ to avoid children crossing too many roads as it is not safe for the children. While the other main facilities were also located between the walking catchment of $400 \mathrm{~m}-1600 \mathrm{~m}$, as shown in Fig. 2. The theoretical concept from the master plan is illustrated with the help of $400 \mathrm{~m}$ radius and $800 \mathrm{~m}$ radius drawn around the school of each precinct selected for the study.

To check the planning standards for accessibility criteria for walkability two planning standard reports were referred. The first one was the Local Plans of Putrajaya (2002) and the second one was the Putrajaya review of the Master Plan [16]. The comparison of the recommended distance between residences to public facilities is presented in Table 4 . 


\begin{tabular}{|c|c|c|}
\hline \multicolumn{2}{|c|}{$\begin{array}{c}\text { Table 4: Required Walking Distance from center } \\
\text { of School to public amenities for walking } \\
\text { catchments consideration }\end{array}$} \\
\hline $\begin{array}{c}\text { Public } \\
\text { Amenties }\end{array}$ & $\begin{array}{c}\text { Walking } \\
\text { distance } \\
\text { threshold } \\
\text { adopted in the } \\
\text { JPBD housing } \\
\text { planning } \\
\text { guidelines }\end{array}$ & $\begin{array}{c}\text { Walking } \\
\text { distance } \\
\text { threshold } \\
\text { adopted in the } \\
\text { Putrajaya } \\
\text { Master Plan }\end{array}$ \\
\hline $\begin{array}{c}\text { Commercial } \\
\text { Centre }\end{array}$ & $600 \mathrm{~m}-3200 \mathrm{~m}$ & $\begin{array}{c}400 \mathrm{~m}- \\
1600 \mathrm{~m}\end{array}$ \\
\hline School & $800 \mathrm{~m}-1600 \mathrm{~m}$ & $\begin{array}{c}400 \mathrm{~m}- \\
1600 \mathrm{~m}\end{array}$ \\
\hline $\begin{array}{c}\text { Neighbourhoo } \\
\mathrm{d}\end{array}$ & $800 \mathrm{~m}$ & $400 \mathrm{~m}-800 \mathrm{~m}$ \\
Playground & & $800 \mathrm{~m}-$ \\
\hline Institutional & $800 \mathrm{~m}-3200 \mathrm{~m}$ & $3200 \mathrm{~m}$ \\
\hline Religious & $800 \mathrm{~m}-3200 \mathrm{~m}$ & $800 \mathrm{~m}-$ \\
& & $3200 \mathrm{~m}$ \\
\hline Parks & $\begin{array}{c}\text { Where two } \\
\text { neighbourhood } \\
\text { s are } \\
\text { connecting }\end{array}$ & $\begin{array}{c}\text { Each } \\
\text { neighbourhoo } \\
\mathrm{d}\end{array}$ \\
\hline
\end{tabular}

Source: Putrajaya Review Master Plan 1997

\subsubsection{Exploration of Proximity for Highest Walkability Precinct 18}

On a walking catchment of $400-800 \mathrm{~m}$ radius proximity analysis is done as recommended by the local plans and review of the master plan. From school center, 400-800 meter radius walking catchments area is mapped, as shown in Fig. 3. Most people are comfortable walking within 400-800 metres radius (about 5 minutes) buffer regularly. Walkability catchments which are also known as pedsheds, provide maps showing the actual area within a five to ten minutes walking distance from any centre of a neighbourhood.

The Threshold distance in Table 4 from the recommendation in both local plan as well as the master plan of Putrajaya, Malaysia is considered for this study by proximity measures command in Arc GIS. With the help of proximity analysis command buffers or multiple buffers are generated. Multiple ring buffers are generated in this study as with the use of multiple buffer one can set several different distances radii around the same point to see how many

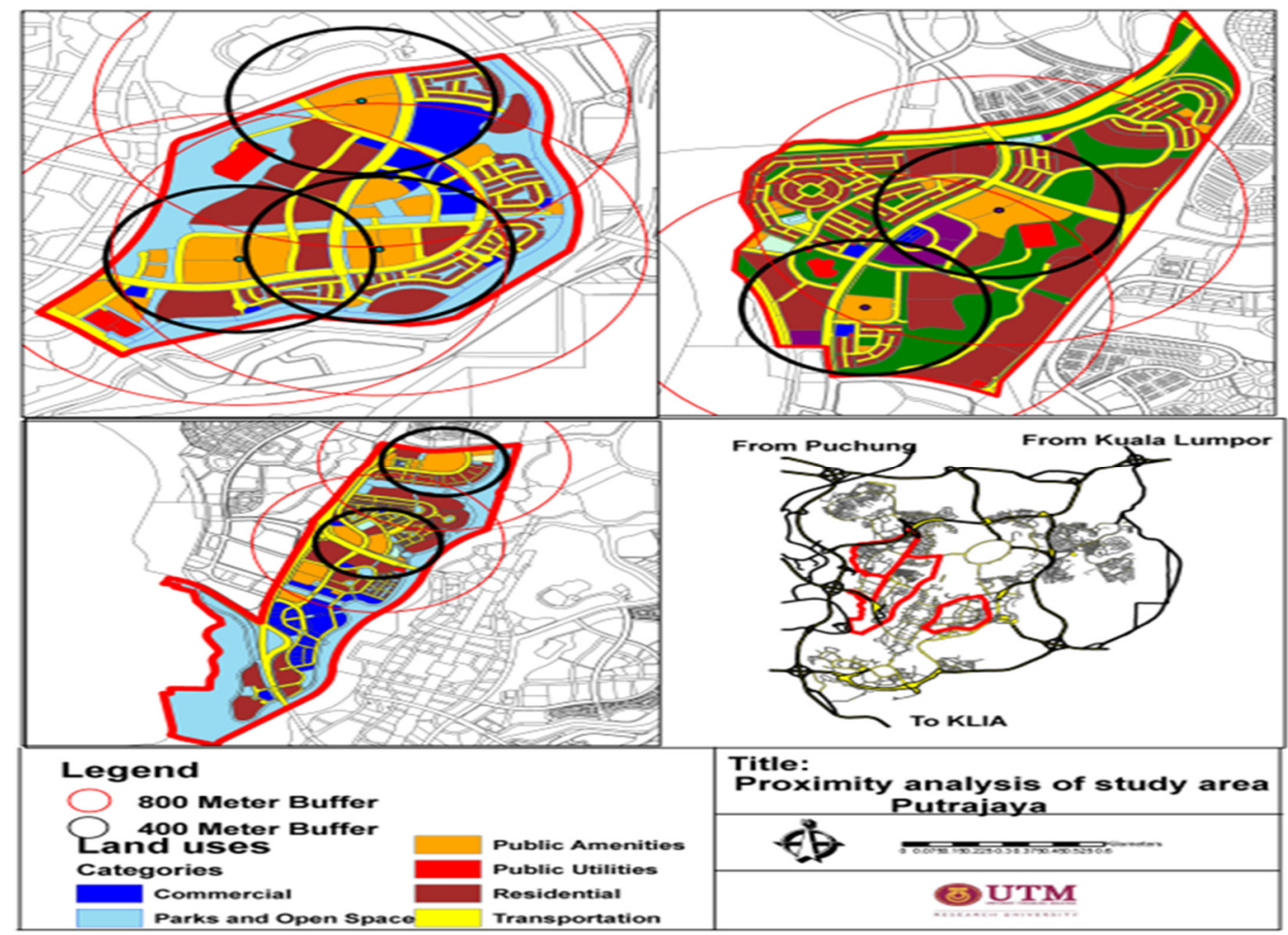

Fig. 2: $400 \mathrm{~m}$ and $800 \mathrm{~m}$ radius illustrating walking catchments [9] 
facilities lie within a 5,10,15 minutes walking distance. Following distances were obtained as shown in Table 5 with the help of proximity analysis tool in arc GIS [17, 18].

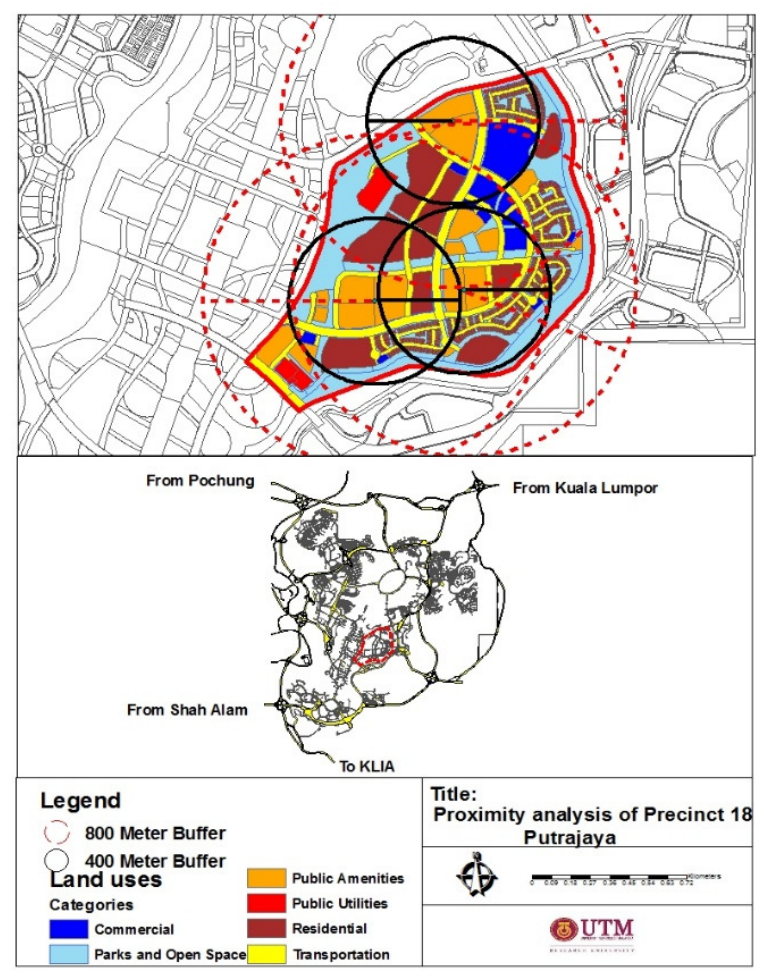

Fig. 3: $400 \mathrm{~m}$ and $800 \mathrm{~m}$ radius exploring proximity in highest walkability Precinct 18 [9]

Table 5: Public amenities within the range of radius 1, 2, 3 (400 meter) and 4,5,6 (800 meter)

\begin{tabular}{|l|c|}
\hline Public Amenities & $\begin{array}{c}\text { Catchment radius for } \\
\text { walking }\end{array}$ \\
\hline Kindergarten & $400 \mathrm{~m}$ \\
\hline $\begin{array}{l}\text { Elementary and middle } \\
\text { school }\end{array}$ & $400 \mathrm{~m}$ \\
\hline High school & $800 \mathrm{~m}-1600 \mathrm{~m}$ \\
\hline Housing & $400 \mathrm{~m}-800 \mathrm{~m}$ \\
\hline Park and open spaces & $400 \mathrm{~m}-1600 \mathrm{~m}$ \\
\hline commercial & $400 \mathrm{~m}-800 \mathrm{~m}$ \\
\hline Mosque, prayer room & $400 \mathrm{~m}-800 \mathrm{~m}$ \\
\hline Bus stop & $400 \mathrm{~m}-800 \mathrm{~m}$ \\
\hline
\end{tabular}

The radius is drawn using the GIS multiple ring buffers in a radius of 400 meters and 800 meters. The mentioned public amenities and the catchment radii in Table 5 also correspond with values in the local plan of Putrajaya and Putrajaya review of the master plan. As the students aged between 4 to 13 are attending the kindergarten elementary school and middle school facilities; therefore, their provision is within a $400 \mathrm{~m}$ radius of a five-minute walking distance. The high school facility is provided within $800 \mathrm{~m}$ to $1600 \mathrm{~m}$ as the High school students are between the age of 14-17 years old; therefore, their provision is within 800meter radius of a five minutes to ten minutes walking distance.

Accessibility is measured with Proximity index by dividing Euclidean distance with Manhattan Distance (equation (2)). In Arc GIS, the Euclidean analysis minimizes the distances. This was attained here from the school's centre to residential block's centre. At the same time, Manhattan Distances also are known as rectilinear distances; the city block distance is an actual distance attained from the shortest angular analysis tool in Arc GIS [13, 14].

Proximity Index $=\frac{\text { Euclidean Distance }}{\text { Manhattan Distance }}$

Proximity Index $=0.94$

\subsubsection{Exploration of proximity for Modest Walkability Precinct 9}

The proximity was measured by using an option multiple ring buffer in proximity toolset. The function of this command is to create multiple buffers at specified distances around the input features. Multiple ring buffers of $400 \mathrm{~m}$ and $800 \mathrm{~m}$ were chosen for this study as the threshold walking distance for Malaysia whenh its tropical climate is $400 \mathrm{~m}$ to $800 \mathrm{~m}$ buffer (see Fig. 4).

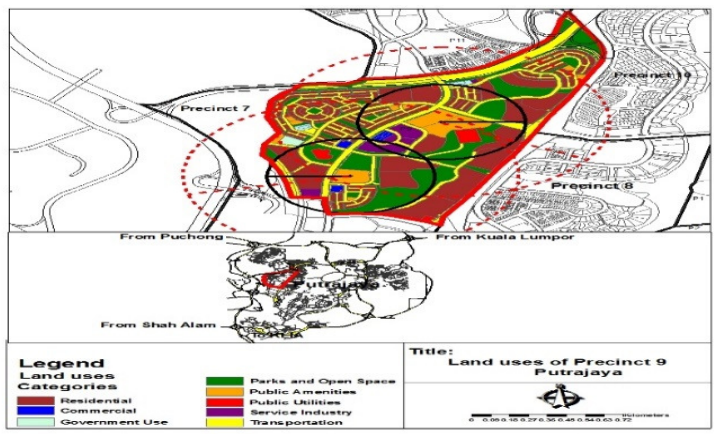

Fig.4: $400 \mathrm{~m}$ and $800 \mathrm{~m}$ radius exploring proximity of Modest Walkability Precinct 9 
The Table 6 and 7 summarize the distance obtained with the help of multiple ring analysis. As the children going to kindergarten are aged between 4 and 5; therefore, kindergarten was located within approximately $400 \mathrm{~m}$ radius equates to about 5 minutes of walk time. The location of elementary and middle school is within $400 \mathrm{~m}$ to $800 \mathrm{~m}$ buffer catchment which equates to about 5 minutes to 10 minutes of walking distance as the age group of school-going children are from 6 to 13 years. The high school facility is provided within $800 \mathrm{~m}$ to $1600 \mathrm{~m}$ as the high school students are adults of age 14 to 17 , so the high school facility is at the distance of $10-15$ minutes.

\begin{tabular}{|c|c|}
\hline $\begin{array}{c}\text { Table 6: Amenities within the range of radius 1 } \\
(400 \mathrm{~m}) \text { and radius 2 }(800 \mathrm{~m})\end{array}$ \\
\hline Public Amenities & $\begin{array}{c}\text { Catchment radius for } \\
\text { walking }\end{array}$ \\
\hline Kindergarten & $400 \mathrm{~m}$ \\
\hline $\begin{array}{c}\text { Elementary and middle } \\
\text { school }\end{array}$ & $400 \mathrm{~m}-800 \mathrm{~m}$ \\
\hline High School & $800 \mathrm{~m}-1600 \mathrm{~m}$ \\
\hline Housing & $400 \mathrm{~m}-800 \mathrm{~m}$ \\
\hline Commercial & $400 \mathrm{~m}-800 \mathrm{~m}$ \\
\hline Mosque & $400 \mathrm{~m}-800 \mathrm{~m}$ \\
\hline Bus Stop & $400 \mathrm{~m}-800 \mathrm{~m}$ \\
\hline
\end{tabular}

\begin{tabular}{|c|c|}
\hline \multicolumn{2}{|c|}{$\begin{array}{c}\text { Table 7: Amenities within the range of radius } 3 \\
(400 \mathrm{~m}) \text { and radius } 4(800 \mathrm{~m})\end{array}$} \\
\hline Public Amenities & $\begin{array}{c}\text { Catchment radius for } \\
\text { walking }\end{array}$ \\
\hline Kindergarten & 400 meter \\
\hline $\begin{array}{c}\text { Elementary and } \\
\text { middle school }\end{array}$ & 400 meter -800 meter \\
\hline High school & 800 meter -1600 meter \\
\hline Housing & 400 meter -800 meter \\
\hline Commercial & 400 meter -800 meter \\
\hline Parks and open spaces & 400 meter -800 meter \\
\hline Prayer room & 400 meter -800 meter \\
\hline Bus terminal & 800 meter -1600 meter \\
\hline Bus stop & 400 meter -800 meter \\
\hline
\end{tabular}

For Proximity index, the ratio of Euclidean distance/Manhattan distance is used. For Euclidean distances crow fly distance was taken from the centroid of school to geographically defined centroid of housing blocks. At the same time, Manhattan Distances were attained following the shortest path distance using Arc GIS.

$$
\begin{aligned}
& \text { Proximity Index }=\frac{\text { Euclidean Distance }}{\text { Manhattan Distance }} \\
& \text { Proximity index }=0.86
\end{aligned}
$$

\subsubsection{Exploration of Proximity for lower walkability Precinct 8}

Multiple ring buffers of $400 \mathrm{~m}$ and $800 \mathrm{~m}$ were created for this study as a Euclidean distance model is applied to this study. The walking catchment for essential facilities as walkers may not always use streets to reach a destination (see Fig.5). With the help of $400 \mathrm{~m}$ and $800 \mathrm{~m}$ buffer it is also easier to identify whether all facilities are within comfortable walking range or not.

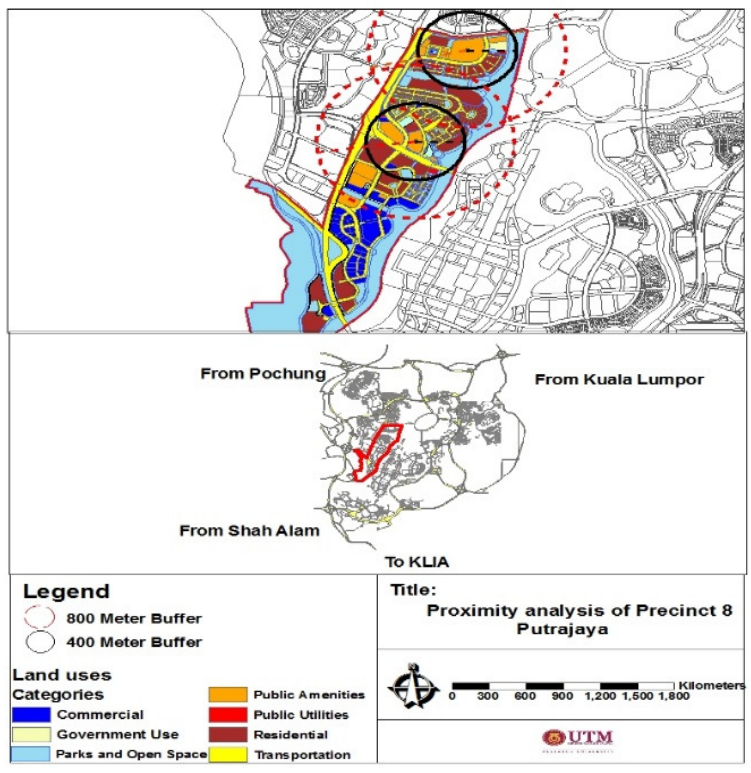

Fig. 5: $400 \mathrm{~m}$ and $800 \mathrm{~m}$ radius exploring proximity of Lower Walkability Precinct 8

The Table 8 and 9 summarizes the distance obtained with the help of multiple ring analysis. As the children going to kindergarten are aged between 4 and 5; therefore, kindergarten was located within approximately $400 \mathrm{~m}$ radius equates to about 5 minutes of walk time. The location of elementary and middle school is within $400 \mathrm{~m}$ to $800 \mathrm{~m}$ buffer catchment which equates to about 5 minutes to 10 minutes of walking distance as the age group of school-going children are from 6 to 13 years. The high school facility is provided within $800 \mathrm{~m}$ to $1600 \mathrm{~m}$ as the high school students are adults of age 14 to 17 , so 
the high school students are adults of age 14 to 17 , so the high school facility is at the distance of $10-15$ minutes.

\begin{tabular}{|c|c|}
\hline $\begin{array}{c}\text { Table 8: Amenities provided the range of radius 1 } \\
(400 \mathrm{~m}) \text { and radius 2 }(800 \mathrm{~m})\end{array}$ \\
\hline Public amenities & $\begin{array}{c}\text { Catchment radius for } \\
\text { walking }\end{array}$ \\
\hline Kindergarten & 400 meter \\
\hline $\begin{array}{c}\text { Elementary school, } \\
\text { middle school }\end{array}$ & 400 meter -800 meter \\
\hline High school & 800 meter -1600 meter \\
\hline Housing & 400 meter -800 meter \\
\hline Commercial & 800 meter -1600 meter \\
\hline Mosque & 400 meter -800 meter \\
\hline Open spaces & 400 meter -800 meter \\
\hline Bus stop & 400 meter -800 meter \\
\hline
\end{tabular}

\begin{tabular}{|c|c|}
\hline \multicolumn{2}{|c|}{$\begin{array}{c}\text { Table 9: Amenities provided in the Range of } \\
\text { radius 3 (400 meter) and radius 4 (800meter) }\end{array}$} \\
\hline Public amenities & $\begin{array}{c}\text { Catchment radius for } \\
\text { walking }\end{array}$ \\
\hline Kindergarten & 400 meter \\
\hline $\begin{array}{c}\text { Elementary school, } \\
\text { middle school }\end{array}$ & 400 meter -800 meter \\
\hline high school & 800 meter -1600 meter \\
\hline Housing & 400 meter -800 meter \\
\hline Commercial center & 400 meter -1600 meter \\
\hline Prayer room & 400 meter -800 meter \\
\hline Open spaces & 400 meter -800 meter \\
\hline Petrol pump & 800 meter -1600 meter \\
\hline Bus stop & 400 meter -800 meter \\
\hline
\end{tabular}

To measure proximity index, Euclidean crows fly distance is divided by Manhattan or city block distance. A $400 \mathrm{~m}$ Euclidean buffer from the school centre is created while Manhattan distance was obtained with the shortest angular path distance of a neighbourhood block with the help of Arc GIS network analysis tool. Referring to Proximity Index equation.

Proximity Index $=\frac{\text { Euclidean Distance }}{\text { Manhattan Distance }}$

Proximity Index $=0.75$

\subsubsection{Measuring network connectivity}

To measure and ensure connectivity the link node ratio which is a connectivity index is used in the previous studies by most planners. The rationale of this index is that a well-connected street grid is likely to have a greater number of links compared with their nodes and there are relatively few dead ends and cul-de-sacs, and more number of four-way intersections. In order to measure the level of connectivity the Link Node Ratio (LNR) is applied here. LNR measures the ratio of links (e) to nodes (v) in the research area[19], referring to equation.

$\beta=\frac{\mathrm{e}}{\mathrm{v}}$

For higher connectivity of the street network for walking purposes, the value of $\beta$ should rise. There is likely to be more pedestrian friendliness when there is a well-connected street network. A $\beta$ value higher than 1.0 signifies that there are many routes choices and more direct travel between numerous destinations. $\beta$ values tend to vary from 0 to 2 .

\subsubsection{Measuring the LNR for the highest walkability found in Precinct 18}

For a walkable community, LNR values range mostly from 1.2 to 1.4 or greater. Cary, North Carolina, San Antonio, San Diego and Texas require in their town regulations a link node ratio of 1.2 whereas Delaware, Florida, Orlando and Middletown require 1.4. It is likewise discovered that the link node ratio is generally higher on a grid iron street pattern as they are pedestrian-friendly consequently dead ends would be less.

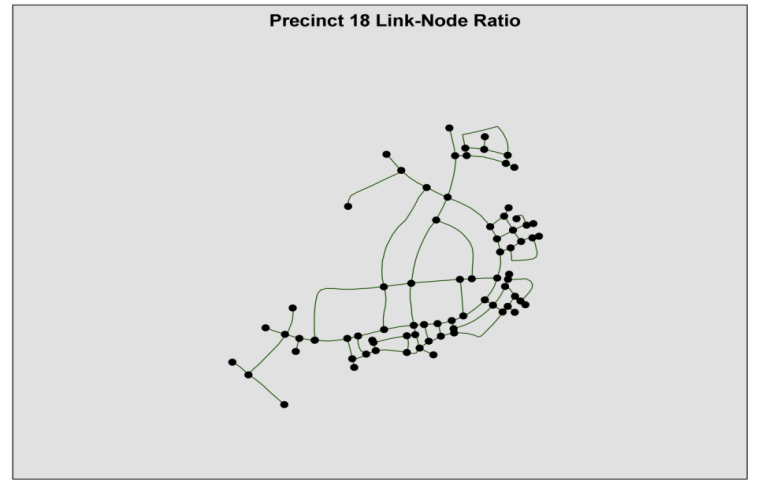

Fig. 6: Highest Walkability Precinct 18's Link Node Ratio 
As illustrated in Fig. 6, a connectivity index here is 1.2. as there are 95 edges besides 79 vertices; consequently, we get an index of 1.2. As discussed earlier, a connectivity index of 1.2 is required for a community to be walkable.

\subsubsection{Measuring Link-Node Ratio (LNR) for modest walkability found in Precinct 9}

Studies on walkability recommend that a link-node ratio between 1.2 and 1.4, represents an excellent target for network planning of a street. In the United States, three major cities have recommended the standards for link-node ratio between 1.2 to 1.4.

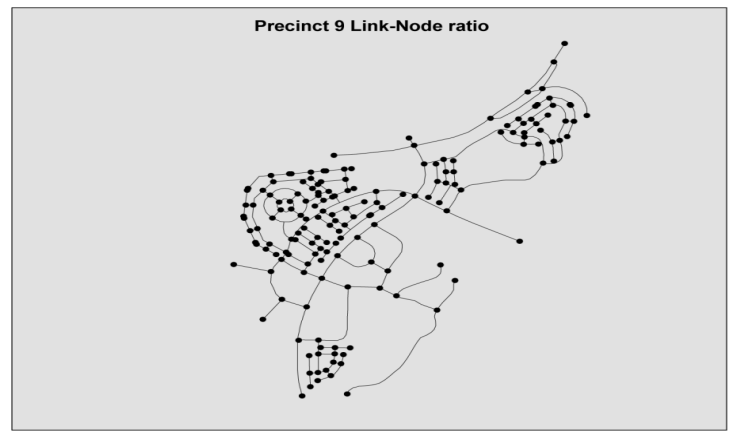

Fig. 7: Modest Walkability Precinct 9's Link Node Ratio

$\beta=\frac{158}{174}=0.90$

As illustrated in Fig. 7, a connectivity index here is 0.9. as there are 158 edges besides 174 vertices, consequently we get an index of 0.90 . As discussed earlier, a connectivity index of 1.2 is required for a walkability neighbourhood, as the obtained value is close to 1 consequently precinct 9 is modest walkability neighbourhood.

\subsubsection{Measuring Link-Node Ratio (LNR) for lower walkability found in Precinct 8}

$\beta=\frac{177}{81}=0.97$

As illustrated in Fig. 8, a connectivity index here is 0.97 as there are 177 edges besides 181 vertices, consequently we get an index of 0.97 , as discussed earlier, a connectivity index of 1.2 is required for a walkability neighbourhood. Since the density of precinct 8 is lower and the most residence categories in this precinct are detached single-family houses, therefore, residents here are not so much willing for a walk.

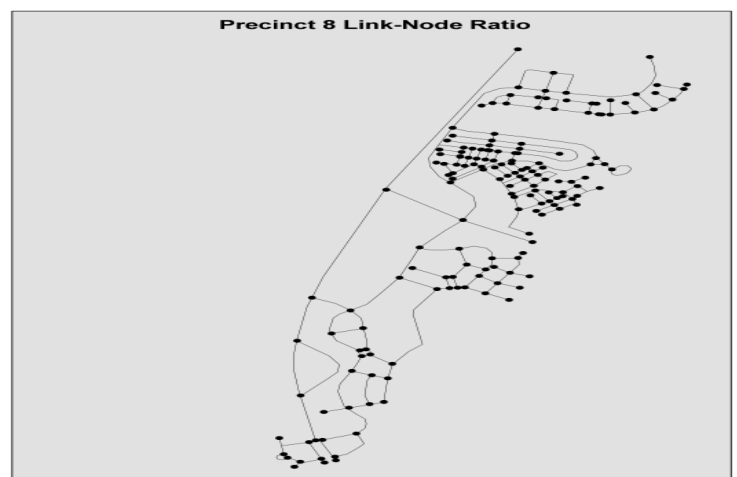

Fig.8: Lower Walkablity Precinct 8's Link Node Ratio

The result presented in Table 10 indicates that residents with high walkability index living in precinct 18 opt for walking more as against residents of precinct 8 as well as 9 . Results also indicate that the residents of the Precinct 18 which is highly walkability residents in precinct 18 daily walk twice the distance covered by residents of Precinct 9 which is a modest walkability precinct having a walk of $1.8 \mathrm{~km}$ per day. The residents of precinct 8 which has a lower walkability walk approximately $0.82 \mathrm{~km}$ distance per day.

\begin{tabular}{|c|c|c|c|}
\hline \multicolumn{4}{|c|}{ Table 10: Precinct 18,9 And 8 Beta $(\beta)$ Values } \\
Determined \\
\hline & $\begin{array}{c}\text { Highest } \\
\text { Walkability } \\
\text { Precinct } 18\end{array}$ & $\begin{array}{c}\text { Modest } \\
\text { Walkability } \\
\text { Precinct } 9\end{array}$ & $\begin{array}{c}\text { Lower } \\
\text { Walkability } \\
\text { Precinct } 8\end{array}$ \\
\hline \multicolumn{1}{|c|}{ Beta( $\beta)$} & 1.2 & 0.90 & 0.97 \\
\hline $\begin{array}{l}\text { Pedometer } \\
\text { distance } \\
\text { (mean) }\end{array}$ & $\begin{array}{l}2.6 \mathrm{~km} / \text { day } \\
(\mathrm{n}=134)\end{array}$ & $\begin{array}{l}1.8 \mathrm{~km} / \text { day } \\
(\mathrm{n}=134)\end{array}$ & $\begin{array}{l}0.82 \mathrm{~km} / \text { day } \\
(\mathrm{n}=134)\end{array}$ \\
\hline
\end{tabular}

\section{RESULTS AND DISCUSSION}

The result presented in Table 11 shows a comparative analysis of three neighbourhoods of Putrajaya in Malaysia that differ objectively on four built environment attributes: compactness, diversity, proximity and connectivity. These attributes impact walkability on a neighbourhood scale. The results indicate that the over-all indices values of Precinct 18 
are high. Pedometer readings for Precinct 18 were are also significantly higher than Precinct 8 and Precinct9. Residential densities of Precinct 9 are comparatively lower than precinct 18 but are higher than Precinct 8. Diversity index values are also higher for Precinct 18 as Precinct 18 has more number of land uses. The proximity index value is also high for Precinct 18 compared to the other two precincts primarily because different destinations in Precinct 18 are in close proximity. The connectivity index value is also high for Precinct 18 as there is more number of short-cuts to reach several destinations compared to the other two precincts. Overall, the index value for Precinct 9 is lesser in comparison with precinct 18 however higher to Precinct 8. Pedometer recorded distance for Precinct 9 is also lower in comparison with precinct 18 yet greater than that of Precinct 8 . Therefore, this study concludes that the attributes of the built environment were associated with Pedometer determined walkability.

\begin{tabular}{|c|c|c|c|c|}
\hline \multicolumn{5}{|c|}{$\begin{array}{c}\text { Table 11: Objective Measures of Built Environment Attributes Influencing Walkability and Pedometer } \\
\text { Findings }\end{array}$} \\
\hline Attributes & Criteria & $\begin{array}{l}\text { Highest walkability } \\
\text { Precinct } 18\end{array}$ & $\begin{array}{l}\text { Modest walkability } \\
\text { Precinct } 9\end{array}$ & $\begin{array}{c}\text { Lower walkability } \\
\text { Precinct } 8\end{array}$ \\
\hline \multirow[t]{2}{*}{ Compactness } & Gross residential densities & $\begin{array}{c}24.8 \\
\text { Housing units/Acres }\end{array}$ & $\begin{array}{c}20.5 \\
\text { Housing units/Acres }\end{array}$ & $\begin{array}{c}8.33 \text { Housing } \\
\text { units/Acres }\end{array}$ \\
\hline & Gross plot ratio & Up to 2.1 & Up to 1.6 & Up to 1.4 \\
\hline Diverse land uses & Simpsons diversity index (D) & 0.941 & 0.632 & 0.309 \\
\hline \multirow[t]{5}{*}{ Accessibility } & \multirow[t]{3}{*}{ Multiple ring analysis } & $\begin{array}{c}\text { @ 400meter } \\
\text { Kindergarten } \\
\text { Elementary and } \\
\text { Middle school }\end{array}$ & $\begin{array}{c}\text { @ 400meter } \\
\text { Kindergarten }\end{array}$ & $\begin{array}{l}\text { @ 400meter } \\
\text { Kindergarten }\end{array}$ \\
\hline & & $\begin{array}{c}\text { @ 400-800meter } \\
\text { i, Housing facilities. } \\
\text { ii, Shops and offices } \\
\text { (commercial) } \\
\text { iii, Religious } \\
\text { facilities } \\
\text { (mosque,prayer } \\
\text { room) } \\
\text { iv, Bus stop }\end{array}$ & $\begin{array}{c}\text { @ 400-800meter } \\
\text { i, Elementary and } \\
\text { Middle School } \\
\text { ii, Housing Facilities } \\
\text { iii, Shops and offices } \\
\text { (commercial) } \\
\text { iv, Religious } \\
\text { facilities } \\
\text { (Mosque and prayer } \\
\text { room) } \\
\text { v. Bus stop } \\
\text { vi,openspaces } \\
\end{array}$ & $\begin{array}{l}\text { @ 400-800meter } \\
\text { i, Elementary and } \\
\text { Middle School } \\
\text { ii,Housing Facilities } \\
\text { iii, Religious } \\
\text { facilities } \\
\text { (mosque, prayer } \\
\text { room) } \\
\text { iv, open spaces } \\
\text { v, Bus stop }\end{array}$ \\
\hline & & $\begin{array}{l}\text { @ } 400-1600 \mathrm{~m} \\
\text { i, Parks and } \\
\text { openspaces }\end{array}$ & & $\begin{array}{c}@ 400-1600 \\
\text { i, Shops and offices }\end{array}$ \\
\hline & & $\begin{array}{l}\text { @ } 800-1600 \mathrm{~m} \\
\text { i, High school }\end{array}$ & $\begin{array}{l}\text { @ } 800-1600 \mathrm{~m} \\
\text { i, High school } \\
\text { ii, Bus terminal }\end{array}$ & $\begin{array}{c}\text { @ 800-1600m } \\
\text { i, High school } \\
\text { ii, Shops and offices } \\
\text { (commercial) } \\
\text { iii, Petrol pump }\end{array}$ \\
\hline & Proximity index & 0.94 & 0.86 & 0.75 \\
\hline Connectivity & Link-Node Ratio $(\beta)$ & 1.2 & 0.90 & 0.97 \\
\hline \multicolumn{5}{|c|}{ Direct observational measures (Objective) } \\
\hline Indicator & & Precinct 18 & Precinct 9 & Precinct8 \\
\hline $\begin{array}{l}\text { Threshold distance } \\
\text { (mean) }(\mathrm{Km} / \text { day }) \\
(\mathrm{n}=402)\end{array}$ & \multirow[t]{2}{*}{ Pedometer readings } & 2.6 & 1.8 & 0.82 \\
\hline $\begin{array}{c}\text { Steps } \\
\text { Recorded/day }\end{array}$ & & 3108 & 1995 & 995 \\
\hline
\end{tabular}

\section{CONCLUSION}

This paper supports the that objective measures of neighbourhood design are significantly associated with the pedometer determined different level of walkability. The results of this study support the rationale for the development of policy that promotes increased level of compactness, diverse land uses, accessibility and connected street network as interventions for neighbourhood walkability. To objectively measure built environment attributes, the GIS data was used to construct built environment 
attributes measures. This study adds to mounting evidence referring that both urban planners and urban designers have the capability to plan and design a neighbourhood that encourages walking. The result obtained in the present study shows that the neighbourhood's attributes of built environment, i.e. compactness, diverse land uses, proximity influence walkability. Earlier studies also found that neighbourhood with high compactness, diverse neighbourhood, more connected street pattern and access to basic amenities encouraged residents to choose non-motorized transport mode such as walking. Therefore, it can be concluded that future neighbourhood designs in hot regions like Malaysia and Pakistan must be more pedestrian friendly.

\section{ACKNOWLEDGEMENT}

The authors would like to thank Mehran University of Engineering and Technology, Jamshoro for facilitating this research and anonymous reviewers are also acknowledged for their diligent reviews and constructive comments.

\section{REFERENCES}

1. Hajna S., Ross N. A., Brazeau A. S., Bélisle P., Joseph L., Dasgupta K., "Associations between Neighbourhood walkability and daily steps in adults: a systematic review and meta-analysis", BMC Public Health, Vol. 15, No. 1, pp.768-778, 2015.

2. Adkins A., Makarewicz C., Scanze M., Ingram M., Luhr G., "Contextualizing Walkability: Do Relationships Between Built Environments and Walking Vary by Socioeconomic Context?", Journal of the American Planning Association, Vol. 83, No. 3, pp. 296-314, 2017.

3. Leslie E., Cerin E., Dutoit L., Owen N., Bauman. A. 'Residents' perceptions of walkability attributes in objectively different Neighbourhoods: A pilot study", Health and Place, Vol. 11, No. 3, pp. 227-236, 2005.

4. Fang Z., Li Q. Shaw S. L., "What about people in pedestrian navigation?", Geo-Spatial Information Science, Vol. 18, No. 4, pp. 135-150, 2015.

5. Park S., Choi K. Lee J. S., "To Walk or Not to Walk: Testing the Effect of Path Walkability on Transit Users' Access Mode Choices to the
Station, Vol. 9, No. 8, pp. 529-541”, International Journal of Sustainable Transportation, 2015.

6. Qureshi S., Shaikh J. M., Memon S. A., "Residents's Subjective Assessment of Walkability Attributes in Objectively Assessed Neighbourhoods", Mehran University. Research Journal of Engineering and Technology, Vol. 37, No. 3, pp. 673-680, 2018.

7. Zhou S., Wang R., Ding J., Pan X., Zhou S., Fang F., Zhen W., "An approach for computing routes without complicated decision points in landmarkbased pedestrian navigation", International Journal of Geographical Information Science., Vol. 33, No. 9, pp.1829-1846. 2019.

8. Oyeyemi A. L., Sallis J. F., Deforche B., Oyeyemi A. Y., De Bourdeaudhuij I., Van Dyck D., "Evaluation of the neighbourhood environment walkability scale in Nigeria", International Journal of Health Geographics, Vol. 12, No. 1, pp. 16-26, 2013.

9. Qureshi S., “Assessing Built Environment Attributes of Walkable Neighbourhood in Malaysian Cities: The Study of Putrajaya”, Ph.D. Thesis, Universiti Teknologi Malaysia, Malaysia, 2017.

10. Tangney C., Carlson K. M., Kwasny, M. J., Rockway, S., Staffileno B., "Validation of Omron Pedometer and Yamax DigiWalker against criterion hand tally", Gazzetta Medica Italiana Archivio per le Scienze Mediche, Vol.170, No. 2, pp.93-102, 2011.

11. Leslie E., Cerin E., Dutoit L., Owen N., Bauman A., "Objectively assessing 'walkability' of local communities: Using GIS to identify the relevant environmental attributes", GIS for Health and the Environment, pp.91-104, Springer, Berlin, Heidelberg, 2007.

12. Lawhon L. L., "The neighbourhood unit: Physical design or physical determinism?", Journal of Planning History, Vol. 8, No.2, pp.111-132, 2009.

13. Qureshi S., Ho C. S., "Towards Putrajaya Green City 2025 Planning Strategy for Sustainability", APSA Congress, pp. 409-420, 2011.

14. Majid M. R., Nordin A. N., Medugu I. N., "Influence of housing development designs on 
household vehicle miles traveled: A case of Iskandar Malaysia", Transportation Research Part D: Transport and Environment, Vol. 1, No. 33, pp.63-73, 2014.

15. Putrajaya, P., "Local Plan Putrajaya Precincts 7, 8, 9, and 10", Putrajaya: Perbadanan Putrajaya, 2002.

16. Putrajaya P., "Putrajaya Review of Master Plan", Putrajaya: Perbadanan Putrajaya, 1997.

17. La Rosa D., "Accessibility to greenspaces: GIS based indicators for sustainable planning in a dense urban context", Ecological Indicators, Vol. 1, No.42, pp.122-134, 2014.
18. McCormack G. R., Giles-Corti B., Bulsara, M., "The relationship between destination proximity, destination mix and physical activity behaviors", Preventive Medicine, Vol. 46, No. 1, pp. 33-40, 2008.

19. Berrigan D., Pickle L. W., Dill J., "Associations between street connectivity and active transportation", International Journal of Health Geographics, Vol. 9, No.1, pp. 20-30, 2010. 